\title{
Effects of Microbial and Heavy Metal Contaminants on Environmental/Ecological Health and Revitalization of Coastal Ecosystems in Delaware Bay
}

\author{
Gulnihal Ozbay *, Lathadevi K. Chintapenta, Amy Cannon and Kenneth Hannum \\ Department of Agriculture and Natural Resources, College of Agriculture and Related Sciences, Delaware State University, \\ Dover, DE, United States
}

OPEN ACCESS

Edited by:

Mohiuddin Md. Taimur Khan, Washington State University,

United States

Reviewed by:

Nehreen Majed,

University of Asia Pacific, Bangladesh

Juan M. Gonzalez,

Consejo Superior de Investigaciones Cientificas (CSIC), Spain

Devendra P. Saroj,

University of Surrey, United Kingdom

*Correspondence: Gulnihal Ozbay gozbay@desu.edu

Specialty section:

This article was submitted to

Environmental Health,

a section of the journal

Frontiers in Environmental Science

Received: 08 February 2017

Accepted: 18 May 2017

Published: 07 June 2017

Citation:

Ozbay G, Chintapenta LK, Cannon A and Hannum K (2017) Effects of

Microbial and Heavy Metal Contaminants on

Environmental/Ecological Health and Revitalization of Coastal Ecosystems in Delaware Bay.

Front. Environ. Sci. 5:26.

doi: 10.3389/fenvs.2017.00026
The presence of heavy metals, excess nutrients, and microbial contaminants in aquatic systems of coastal Delaware has become a public concern as human population increases and land development continues. Delaware's coastal lagoons have been subjected to problems commonly shared by other coastal Mid-Atlantic states: turbidity, sedimentation, eutrophication, periodic hypoxic/anoxic conditions, toxic substances, and high bacterial levels. The cumulative impact of pollutants from run-off and point sources has degraded water quality, reduced the diversity and abundance of various fish species, invertebrates, and submerged aquatic vegetation. The effects are especially pronounced within the manmade dead end canal systems. In this article, we present selected case studies conducted in the Delaware Inland Bays. Due to the ecological services provided by bivalves, our studies in Delaware Inland Bays are geared toward oysters with special focus on the microbial loads followed by the water quality assessments of the bay. The relationships between oysters (Crassostrea virginica), microbial loads and nutrient levels in the water were investigated. The heavy metal levels monitored further away from the waste water treatment plant in the inland bays are marginally higher than the recommended EPA limits. Also, our studies confirmed that aerobic bacteria and Vibrionaceae levels are salinity dependent. Total bacteria in oysters increased when nitrate and total suspended solids increased in the waters. Studies such as these are important because every year millions of Americans consume raw oysters. Data collected over the last 10 years from our studies may be used to build a predictive index of conditions that are favorable for the proliferation of human pathogenic bacteria. Results from this study will benefit the local community by helping them understand the importance of oyster aquaculture and safe consumption of oysters while making them appreciate their ecological and commercial values. This will also be of tremendous help to the commercial shellfish aquaculture farms to predict poor conditions to prevent oysters' consumption when bacterial levels are high in water.

Keywords: environmental monitoring, oysters, heavy metals, water quality 


\section{INTRODUCTION}

\section{Overview of Environmental Health and Practices in Coastal Delaware}

Coastal areas are home to a wealth of natural and economic resources and are frequently the most developed and disturbed areas. This narrow fringe, comprising 17 percent of the contiguous U.S. land area, is home to more than half of the nation's population (NOAA, 2004). Among scholars, there is a general consensus that the current rates of resource depletion and environmental degradation cannot be sustained over a long period of time. It is crucial that consideration is given to human impact on the coastal ecosystems. The costal ecosystems that we have been continuously monitoring during the last 10 years are located in the Delaware Inland Bays. Our research group has performed various studies focusing on water nutrient quality, oyster bacteriological quality, and assessment of heavy metals in the waters. In this article, we will be presenting selected case studies from our research program which will focus on coastal ecosystem health and management.

\section{Delaware Inland Bays-Southern Delaware}

Delaware Inland Bays (DIB) are the key focus areas in this study, they consist of three shallow coastal bays, namely Rehoboth, Indian River, and Little Assawoman. These bays cover $\sim 215$ $\mathrm{km}^{2}$ and have an average depth of $1.2 \mathrm{~m}$ (Chaillou et al., 1996). These Inland Bays drain a watershed that is being rapidly developed. Because these bays are very shallow (i.e., $1-2.4 \mathrm{~m}$ depth) and are poorly flushed by tidal movement, they are especially sensitive to environmental changes. Low flushing rates also contribute to the buildup of nutrients in the bay. While the flushing rate for Little Assawoman can be as low as 1-7 days, Rehoboth and Indian River bays have relatively slow flushing rates as high as $80-100$ days (DIB Estuary Report, 1993; Chaillou et al., 1996). Due to the high coastal populations in Delaware and poor land use practices these bays suffer from the impacts of chronic eutrophication and sediment erosion (Chaillou et al., 1996; CIB, 2014). The primary source of nutrients in the DIB includes both point and non-point sources (NPS) in watersheds, leaking septic systems, animal waste and fertilizer contained in runoff from agricultural lands (EPA, 2011). MacKenzie et al. (2016) described the formation of these shallow bays as the water bodies behind Atlantic barrier beaches along the eastern edge of the Delmarva coastal plain. MacKenzie et al. (2016) also addressed consistently excess nutrients such as nitrogen, phosphorus, and low dissolved oxygen in these areas because of the intensive corn, soybean, and poultry production and a large coastal tourism industry. Figure 1 shows the nutrient loads reduction of point sources discharges from Townsend/Mountaire processing plant and Rehoboth wastewater treatment plan.

These industries support a major portion of Delaware's economy, but they have had and continue to have impacts on local water quality. These NPS can lead to increased levels of heavy metals along with other nutrients in these waters. A variety of commercially and environmentally important species such as weakfish, spot, blue fish, Atlantic menhaden, hard clams, blue crabs, and eastern oysters (DIB Estuary Report, 1993) are present in DIB's. The National Oceanic and Atmospheric Administration (NOAA) monitors levels of metals using mussels and oysters all around our nation's coasts, and comprises these levels in a report called the mussel watch report (Kimbrough et al., 2008). This document shows Delaware having regionally medium levels of cadmium $(\mathrm{Cd})$ and regionally high levels of lead $(\mathrm{Pb})$ (Kimbrough et al., 2008). The information about $\mathrm{Cd}$ and $\mathrm{Pb}$ is essential because the U. S. Environmental Protection Agency (EPA, 2011) states that $\mathrm{Cd}$ and $\mathrm{Pb}$ can both cause health problems when ingested, as in the case of water. In addition, the U. S. Geological Survey and others, report wastewater treatment and industrial facilities as being potential sources for heavy metals

\section{Loads of Nutrients from Point Sources Discharging to Rehoboth and Indian River Bay over Time}

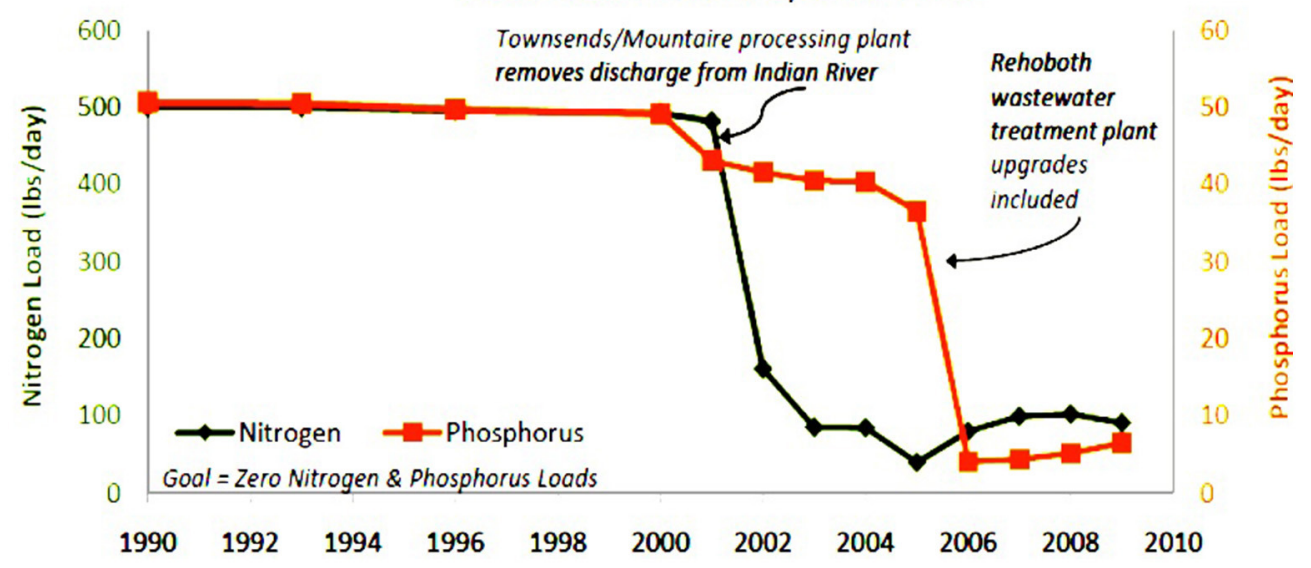

FIGURE 1 | Reduction of nutrient loads from point sources discharges in Rehoboth and Indian River Bay from 1990 to 2009 (http://www.inlandbays.org). 
in aquatic systems (Garbarino et al., 1995; Akpor and Muchie, 2010).

The case studies mentioned in this article are mainly focused on the eastern oysters, Crassostrea virginica, which are keystone species. Abundant populations of eastern oysters provide ecological, environmental, and commercial values to their surrounding areas and have been harvested as a food source for thousands of years (NOAA NMFS, 2007). Around 83,645 tons were annually harvested around the nation from 2005 to 2012 (NOAA NMFS, 2012). Raw oysters are an important source of calcium, iron, selenium, zinc, vitamin B12, and omega 3 fatty acids (Weisbecker, 2010). Ongoing degradation of DIB's since the late 1800's has led to a dramatic decline in local eastern oyster populations (Brumbaugh et al., 2000). As a response to the declined population of oysters in DIB's, we conducted oyster gardening programs as a means to increase local populations of eastern oysters.

\section{Eastern Oysters in Delaware Inland Bays-Seafood Safety}

Oysters are filter feeders and ensuring that seafood is safe for consumption is always a concern, especially when they are consumed raw. During the filter feeding process disease causing organisms, toxins, environmental contaminants, chemicals and even physical hazards such as glass, wood, and metals may enter the shell fish and are retained in the organism (Delaware Sea Grant, 2016). Bioaccumulation is the process, where concentrations of the pollutants are much higher in the tissue of the organism than the surrounding water and this makes it difficult to determine if oysters are safe to eat based on water quality (Zhen-Gang, 2008; Delaware Sea Grant, 2016). Another biggest concern with consumption of raw oysters is the risk of the bacteria, Vibrionaceae (Iwamoto et al., 2010; Delaware Sea Grant, 2016). Contracting this bacteria through consumption of raw oysters can lead to fever, chills, nausea, vomiting, diarrhea, shock, skin lesions, and in severe cases can lead to death (FDA, 2016).

According to the CDC (2013), Vibrio vulnificus is the harmful bacterium commonly associated with the consumption of raw oysters. V. vulnificus is found throughout coastal United States and in many coastal areas of the world. Conditions that put people at high risk for serious illness or death from $V$. vulnificus infections are: liver disease, iron overload disease (hemochromatosis), diabetes, cancer, stomach disorders (FDA, 2015). Pfeffer et al. (2003) conducted a multiyear study on the ecology of $V$. vulnificus in estuaries of eastern United States focusing on environmental factors controlling the presence and concentrations of $V$. vulnificus, other Vibrio spp. It was founded by Pfeffer et al. (2003) that temperature, turbidity, and dissolved oxygen, estuarine bacteria, and coliforms control the vibrio levels. In a similar work by DePaola (2013), temperature, salinity, $\mathrm{pH}$, and high levels of dissolved organics are primary environmental factors responsible for $V$. vulnificus outbreaks. Vibrio parahaemolyticus is another bacterium that is commonly found in the coastal bay systems of the United States and Canada causing gastrointestinal illness in humans from consuming shellfish, especially oysters during the summer months (CDC, 2013). In the three coastal areas of the United States, a 21-month research conducted by Johnson et al. (2012) investigated the relationship between $V$. parahaemolyticus and $V$. vulnificus in the sediment, oysters and water to the environmental quality. They found strong relationships between the Chlorophyll-a concentrations, salinity, and dissolved organic carbon concentrations. Temperature was found as the primary predictor for annual variation in Vibrio spp. levels in their study. Our research group has carried out extensive studies to analyze the bacterial and heavy metal loads in oysters while correlating the bacterial loads to environmental parameters. Selective case study reports have been described in the below sections.

\section{Case Studies -Monitoring the Levels of Heavy Metals in Coastal Delaware Heavy Metal Monitoring in Delaware Inland Bays Summary}

A 2 years study on the levels of heavy metals present in the effluent of a wastewater treatment facility in a tidal canal in Delaware was performed. This site, along with other proximal locations, was monitored every 1-2 weeks depending upon the weather. Samples were collected using EPA Method 1669 protocols and the heavy metals measured were cadmium and lead. Physical and chemical water quality parameters were also monitored continuously from June 2011 through September 2012 using YSI instruments and protocols. The findings show that the wastewater treatment facility is causing significant amounts of nitrogen and phosphorous to be deposited into the canal, and not the deposition of heavy metals. Levels of heavy metals were low at the wastewater treatment plant discharge while their levels were high near the mouth of the north side of Rehoboth Bay. Overall the levels in the study sites were marginally higher than the EPA limits and may be unsafe for the aquatic ecosystem.

The study site is the Rehoboth beach wastewater treatment plant in Rehoboth beach, Delaware. This facility was originally built in 1935 and was upgraded in 1959 as a primary treatment facility for Rehoboth beach and nearby areas. In 1987, the facility was upgraded once again to become a secondary treatment facility. Once again in 1994 and 1997, the facility was upgraded to include biological nutrient removal and chemical phosphorus removal, utilizing Ferric Chloride $\left(\mathrm{FeCl}_{3}\right)$ as a flocculent for precipitation (Stenger, 2008). Through many years of upgrades, the discharge location is still being required to be removed from the Lewes and Rehoboth Canal by 2018 due to high nutrient content, and is being considered to be moved to an ocean discharge instead of the canal (Globetti, 2015). Once the metals are reintroduced into soils for growing foods, they are percolated back down under and through the soil, and into unconfined aquifers that are used for drinking water. The metals can also wash away during rain events, making their way back into aquatic ecosystems. Metals showing up in local waters are one of the most important indicators of how these pollutants are managed.

Our study is aimed to identify if the heavy metals are accumulating in the water supply surrounding the water facility. Several locations (Figure 2) near the facility were sampled to identify and compare the heavy metal concentrations and 


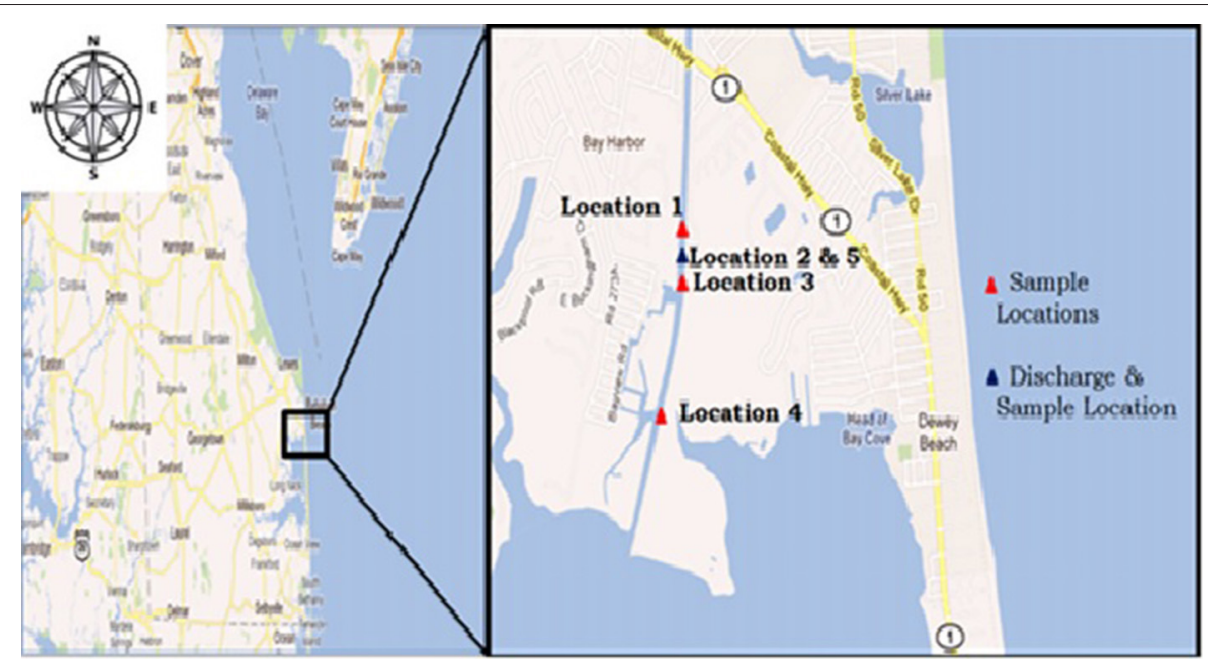

FIGURE 2 | Study locations on the map. Location 5 is separate because this location is the effluent pipe at the wastewater plant. Location 2 is where Location 5 discharge waters are received into the tidal canal (Cannon et al., in press).

other known parameters for determining aquatic health. Water samples were collected weekly in the summer and bi-weekly in the fall and winter months, for duration of 13 months. Sample locations were selected as follows: one location directly at the municipal wastewater treatment facility discharge (Loc. 5), one location $7 \mathrm{~m}$ in front of the discharge, where the discharge water is received directly into the brackish tidal canal (Loc. 2), two more locations, each $\sim 50 \mathrm{~m}$ from the effluent on both the northern (Loc. 1) and southern side (Loc. 3), and a control location near the end of the canal (Loc. 4), $\sim 800 \mathrm{~m}$ away from the discharge, in proximity to the mouth of the Rehoboth Bay. All samples were collected in triplicates to ensure data accuracy. YSI 556 hand held Multi probe was used to monitor on-site physical water quality parameters such as temperature, total dissolved solids (TDS), salinity, dissolved oxygen (DO), and $\mathrm{pH}$. The water samples were processed by nitric acid digestion using EPA method 1637, and tested for heavy metals (cadmium and lead) using a Graphite Furnace Atomic Absorption Spectrophotometer.

The levels of TDS are found to be almost zero at the discharge location, while they remained higher at all other locations with means ranging of $22.25-28.04 \mathrm{~g} / \mathrm{L}$ due to normal mixing in the water column. Salinity levels in the discharge location are 0 and $21.80-27.71 \mathrm{~g} / \mathrm{L}$ at all other locations. The levels of cadmium ranged from 1.3 to $9.2 \mu \mathrm{g} / \mathrm{L}$ (Figure 3A) while the lead concentrations lay between 5.1 and $11.5 \mathrm{ug} / \mathrm{L}$ (Figure 3B) at all the study locations. For Cd, the EPA advises $8.8 \mu \mathrm{g} / \mathrm{L}$ as standards for aquatic ecosystem health considering continual exposure (EPA, 2001). The critical levels of $\mathrm{Pb}$ found in aquatic ecosystems are $5.6 \mu \mathrm{g} / \mathrm{L}$, which is not to be exceeded for more than 4 days in an average of once every 3 years (EPA, 1985). This shows that the heavy metals are marginally higher than the EPA recommended limits. The study results found that the effluent from the treatment facility had the lowest amount of heavy metals than any of the other locations. This may be because the water flows so slowly while it is in the facility that the metals have plenty of time to settle to the bottom and be included in the sludge. Rainfall events also displayed to have minor impacts on the levels of heavy metals at these locations. The average rainfall had positive correlation with lead levels at locations 1 ( $r$ $=0.34)$ and $3(r=0.31)$, showing a potential for the locations directly north and south of the discharge to have been affected by the precipitation entering the canal by way of runoff. No major positive or negative correlations were observed for $\mathrm{Cd}$ in relation to rainfall events in our study (Figure 3C). Figure 3D below shows the relationship between the rainfall and lead levels.

\section{Case Studies-Oyster Safety for Consumption}

\section{Relationships between Environmental Parameters and Microbiological Populations of Oysters from the Lewes-Rehoboth Canal, Delaware}

\section{Summary}

Population densities of Vibrionaceae in waters inhabited by oysters can lead to higher densities of Vibrionaceae within oyster tissues via accumulation. Vibrionaceae can be pathogenic to humans when raw oysters are ingested. Vibrionaceae loads can be fluctuated and have been linked to water temperature and salinity levels. Water and oysters from the Lewes-Rehoboth canal were sampled and tested for total bacteria via colony forming units (CFU) and Vibrionaceae via the COPP assay. During the preliminary research, total aerobic bacterial populations were not found to be correlated with temperature and salinity. Vibrionaceae populations were found to be highly correlated with temperature, while the influence of salinity is less extreme. During the second year, strong correlations were observed between the environmental parameters and Vibrionaceae levels. These findings imply that Vibrionaceae could be modeled to predict periods of high density and warn fisherman when harvesting shellfish from these areas.

Vibrionaceae is a family of bacteria consisting of multiple genera inhabiting brackish water environments (Kaspari and Tamplin, 1993; Randa et al., 2004) that can cause disease in 


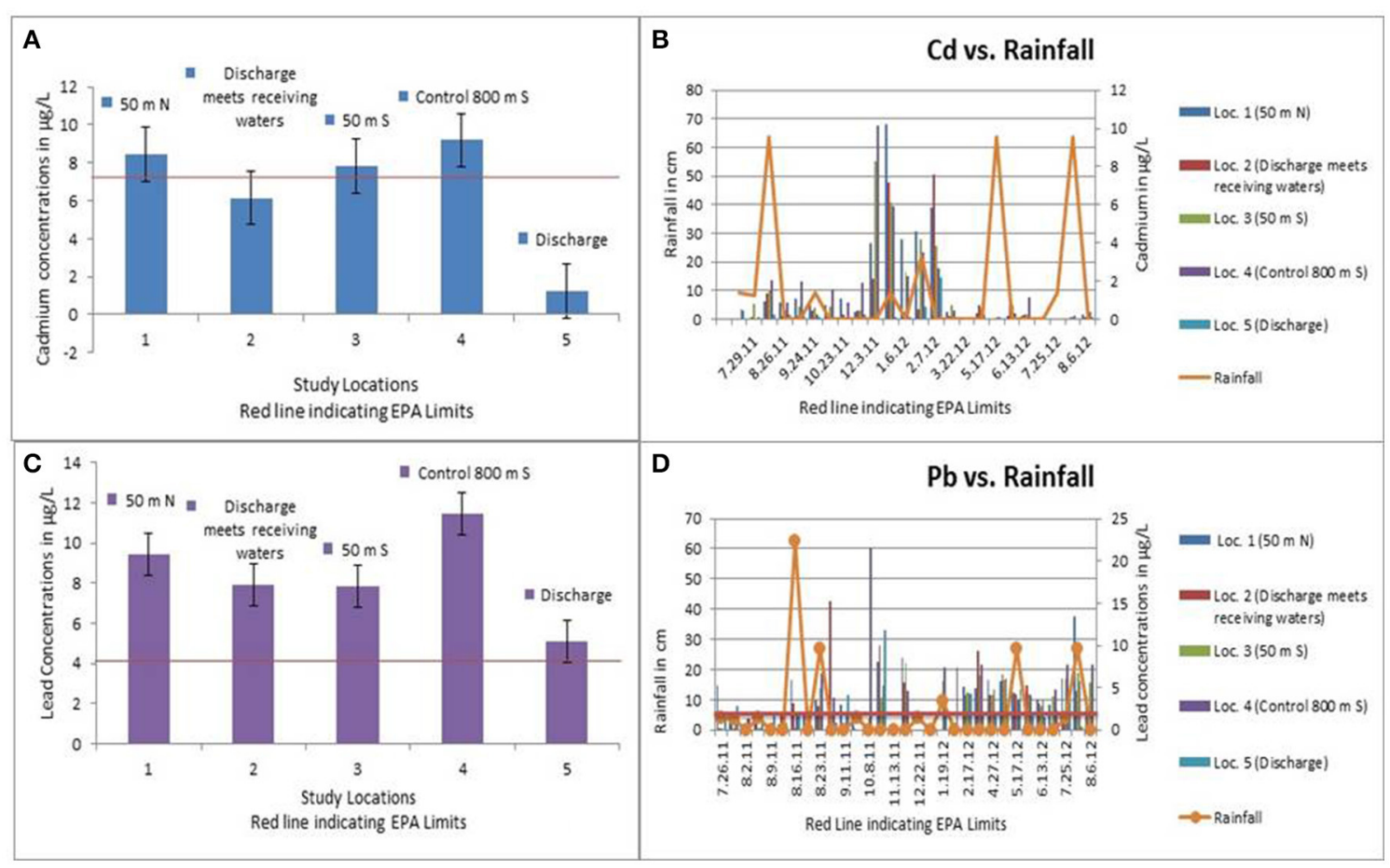

FIGURE 3 | (A) The concentrations of cadmium in the water samples collected from the study locations (Cannon et al., in press). (B) The concentrations of lead in the water samples collected from the study locations (Cannon et al., in press). (C) Relationship between rainfall and cadmium levels in the water samples (Cannon et al., in press). (D) Relationship between rainfall and lead levels in the water samples (Cannon et al., in press).

humans. Vibrionaceae are likely consumed by oysters during filtration and are accumulated in their tissues (Warner and Oliver, 2008). Therefore, Vibrionaceae concentrations in oyster tissues should greatly exceed than that of their adjacent waters. Population densities of some Vibrionaceae species exhibit seasonal fluctuation patterns, with peak densities occurring during the summer and the lowest densities during the winter (Kaspari and Tamplin, 1993; Randa et al., 2004; Warner and Oliver, 2008). Population growth of Vibrionaceae is correlated with temperature and to a lesser extent salinity (Randa et al., 2004 and Warner and Oliver, 2008). Previous studies have shown that regardless of geographical location, Vibrionaceae bacteria are most abundant during the warmer months (DePaola et al., 1990, 2003; Motes et al., 1998; Pfeffer et al., 2003; Randa et al., 2004; Warner and Oliver, 2008). So it is not surprising that the majority of findings indicate a positive correlation between temperature and Vibrionaceae populations in water and oysters as the water temperature increases (Kelly, 1982; DePaola et al., 2003; Pfeffer et al., 2003; Lyons et al., 2007; Warner and Oliver, 2008). It has been observed that Vibrionaceae can be found in water and/or oysters when spring approaches and water temperatures reach $>10^{\circ} \mathrm{C}$ (Wright et al., 1996; Motes et al., 1998; DePaola et al., 2003; Randa et al., 2004; Warner and Oliver, 2008). V. vulnificus was detected in oysters from North Carolina in March when water temperatures were about $11^{\circ} \mathrm{C}$, but was not detected in water until April when water temperatures were still low (Warner and Oliver, 2008). However, V. vulnificus was found in water as low as $7.6^{\circ} \mathrm{C}$ collected from Chesapeake Bay (Wright et al.,
1996). V. vulnificus was also found on the Atlantic and Gulf Coasts inhabiting oysters from waters with temperatures as low as $10.8^{\circ} \mathrm{C}$ (Motes et al., 1998). Other species of Vibrionaceae can also be found at these temperatures. Vibrio parahaemolyticus was cultivated in the laboratory from waters with a temperature of $10^{\circ} \mathrm{C}$ in Mobile Bay, Alabama (DePaola et al., 2003).

Johnson et al. (2012) investigated relationships between environmental parameters and $V$. parahaemolyticus and $V$. vulnificus populations in water, oysters, and sediment samples in three coastal areas of the United States during a 21month study. These authors found strong correlations between sea surface temperature and suspended particulate matter and total and potentially pathogenic $V$. parahaemolyticus and $V$. vulnificus populations. They stated in their research that both these environmental parameters are strong predictors of the presence of these pathogenic bacteria. Other predictors such as total chlorophyll- $a$, salinity, and dissolved organic carbon were also identified. Based on their research assessment, sea surface temperature is a very effective predictor of annual variation in Vibrio abundance while other parameters may be partially responsible for population changes of the Vibrio.

Our study was conducted in the wastewater treatment facility, at Rehoboth Beach, Delaware where heavy metals were monitored (Figure 2). This study expands the understanding of Vibrionaceae population dynamics during the warm summer months and determines if the dynamics that appeared to influence populations in previous studies are similar in Delaware. In addition, the effects of a wastewater discharge that drains 
into the canal on bacterial populations in water and oysters proximate to the discharge were studied. Water temperatures in the Lewes-Rehoboth Canal reach $10^{\circ} \mathrm{C}$ around April, and it is possible that Vibrio bacteria could be found living in the water and/or oysters around this temperature.

Sample locations were selected as follows: one location directly at the municipal wastewater treatment facility discharge (Loc. 5), one location $7 \mathrm{~m}$ in front of the discharge, where the discharge water is received directly into the brackish tidal canal (Loc. 2), two more locations, each $\sim 50 \mathrm{~m}$ from the effluent on both the northern (Loc. 1) and southern side (Loc. 3), and a control location near the end of the canal (Loc. 4), $~ 800 \mathrm{~m}$ away from the discharge, in proximity to the mouth of the bay. Sample collection was performed weekly during the warmer months. Because of the proximity of the locations 2 and 5, we referred both sites as Loc. 2 in our discussion.

Since the oyster population is limited in Delaware waters, eastern oysters were obtained from Delaware's oyster gardening program and placed in aquaculture trays at four locations in the Lewes-Rehoboth Canal, Delaware in this program. Three locations were adjacent to a wastewater discharge and the fourth location was present at a control site about $800 \mathrm{~m}$ away near the mouth of the canal at Rehoboth Bay described as Loc. 4 (Figure 4).

Physical water quality parameters were collected at the time water and oysters were sampled for use in bacterial analysis. Three dilutions for each water sample and oyster homogenate were plated in $100 \mu \mathrm{L}$ amounts on tryptic soy agar plates in triplicate or greater, and incubated at $37^{\circ} \mathrm{C}$ for $18-24 \mathrm{~h}$.
Colony forming units (CFUs) and total bacterial densities were calculated. Counted plates were selected and subjected to the Colony Overlay Procedure for Peptidases (COPP) assay for Vibrionaceae identification as described by Richards et al. (2005) (Figure 5). The population densities for total aerobic bacteria and Vibrionaceae were calculated and compared to temperature, salinity, and other water quality variables tested using the Spearman rank correlation test.

Mean population densities of total aerobic bacteria and Vibrionaceae for all four water sampling locations, treatment (Loc. 2) oysters, and control (Loc. 4) oysters, show that location 3 had the highest mean total bacterial density in water, while Loc. 2 had the highest mean Vibrionaceae density in water. During the preliminary research, total aerobic bacterial populations were not found to be correlated with temperature and salinity levels. Vibrionaceae populations were found to be highly correlated with temperature (Figure 6A), while the influence of salinity was less extreme. Spearman rank correlation analysis revealed no correlations between temperature and total aerobic bacteria or salinity and total bacterial population densities in water. However, analysis did show correlations between temperature and Vibrionaceae and between salinity and Vibrionaceae populations (Figure 6B). These results agree with the findings of other studies mentioned previously, and show that temperature appears to be strongly correlated with Vibrionaceae population dynamics while the influence of salinity on Vibrionaceae populations seem to be less severe. These findings imply that Vibrionaceae population densities could be modeled to predict periods of high density and give warnings to

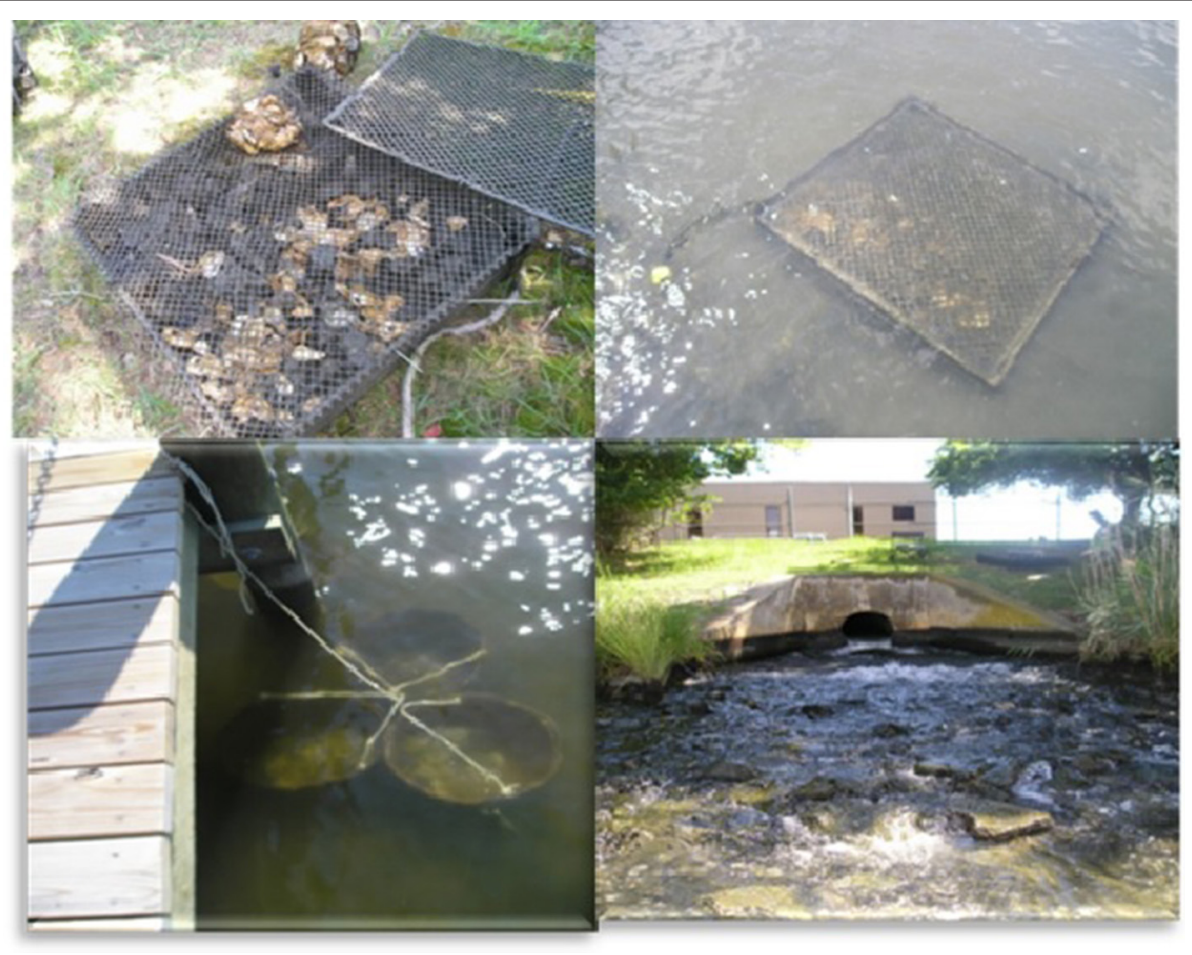

FIGURE 4 | Study locations near the Rehoboth Beach Wastewater Treatment Plant in Rehoboth Beach, Delaware (Cannon et al., in press). 


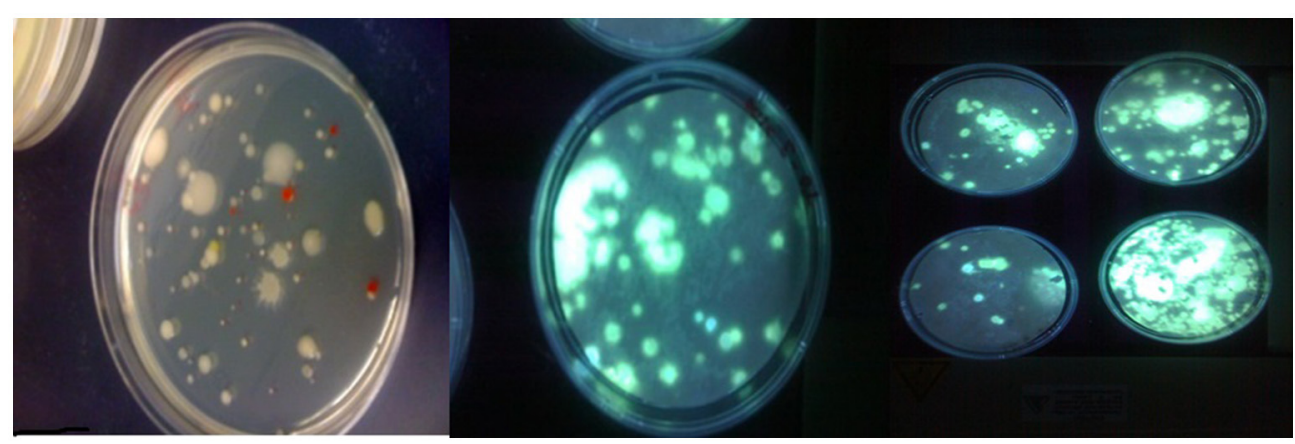

FIGURE 5 | Colony Overlay Procedure for Peptidases (COPP) Assay for Vibrionaceae identification (Hannum, 2007).

fisherman harvesting shellfish from areas predicted to have high densities.

During the second year, strong correlations were observed between temperature and Vibrionaceae, total aerobic bacteria and Vibrionaceae, and turbidity and Vibrionaceae. While some correlations between temperature and total aerobic bacteria, total suspended solids and total aerobic bacteria, turbidity and total aerobic bacteria were recorded, inverse correlation was found between salinity and total aerobic bacteria, salinity and Vibrionaceae, dissolved oxygen and total aerobic bacteria, and dissolved oxygen and Vibrionaceae concentrations. Overall, the highest concentration for both total aerobic bacteria and Vibrionaceae in oysters was found at the control site (Loc. 4) away from the discharge. These results agree with those of previous studies (Kelly, 1982; Singleton et al., 1982; O'neill et al., 1992; Hoi et al., 1998; DePaola et al., 2003; Pfeffer et al., 2003; Lyons et al., 2007; Froelich et al., 2012) that showed similar relationships between the water quality parameters and Vibrionaceae concentrations in oysters observed in our study.

\section{Relationship between Environmental Quality and Total Aerobic Bacteria and Total Vibrionaceae \\ Summary}

Consumption of uncooked oysters is known to cause serious health conditions due to the bioaccumulation of contaminants, especially during the warmer months. Contracting with Vibrionaceae bacteria through consumption of raw oysters can lead to fever, chills, nausea, vomiting, diarrhea, shock, skin lesions, and in severe cases can lead to death. In this research, eastern oysters were exposed to various environmental stresses including high nitrate, low salinity, low and high suspended salts in water. Total aerobic bacteria and Vibrionaceae levels from these oysters were compared to the control oysters and relationships between the environmental parameters and total aerobic bacteria and Vibrionaceae were investigated. Oysters under low salinity treatments consistently yielded the highest total aerobic bacteria and Vibrionaceae levels, followed by the high nitrate treatment oysters, the high average total suspended solids treatment oysters, and the control treatment oysters. Although the salinity treatments had the highest total aerobic bacteria and Vibrionaceae levels, the data was weakly related to the nutrients. Therefore, this study confirms that high aerobic bacteria and Vibrionaceae levels are primarily salinity dependent. Also, when total phosphorus levels were high, total bacteria and Vibrionaceae levels increased.

Oysters are the most harvested shellfish in the world (NOAA NMFS, 2007) they are non-motile marine organisms and are dependent on filtering water to obtain food (Klontz and Rippey, 1991). As filter feeders, oysters ingest bacteria along with their food source, phytoplankton, from their habitat (Oregon Health Authority, 2016). A consequence of filter feeding can be the accumulation of microorganisms which cannot always be removed by purification (Pérez-Mateos et al., 2002), thus concentrating pathogenic bacteria and viruses from polluted water (Cruz-Romero et al., 2008). Raw oysters are not recommended for human consumption during the warm summer months because as filter-feeders, they intake and store more bacteria in their bodies (Taylor, 2013; FDA, 2015), and are known to cause serious health conditions due to the bioaccumulation of these contaminants. The biological, chemical, and ecological status of the Delaware Inland Bays has been studied for many years. Eutrophication within the Bays has deteriorated the water quality conditions and led to the Delaware Inland Bays being identified as impaired waters on the Delaware 1996 Clean Water Act Section 303(d) list, (DNREC, 2005).

Our research group has made efforts to investigate the relationships between water quality, total aerobic bacteria, and total Vibrionaceae at three study sites within the Delaware Inland Bays in 2007. They found a strong correlation between total aerobic bacteria and total phosphorus at study sites and strong relationships between total Vibrionaceae, total nitrogen and total phosphorus at the canal and bay sites, respectively. However, no relationships between Vibrionaceae, total nitrogen and total phosphorus were found for the Indian River site. During the warmer months, two oyster gardening sites were further studied to gather more baseline data using the Colony Overlay Procedure for Peptidases (COPP) assay (Richards et al., 2005). One site was located at the end of a man-made canal and experienced low levels of flushing, whereas the second site was located in an open location within Little Assawoman Bay and experienced high levels of flushing-referred as the canal and bay study sites in the study conducted in 2008. Fay et al. (2011) found the highest Vibrionaceae levels at the canal site in September $\left(3.5 \times 10^{5} / \mathrm{g}\right)$ 


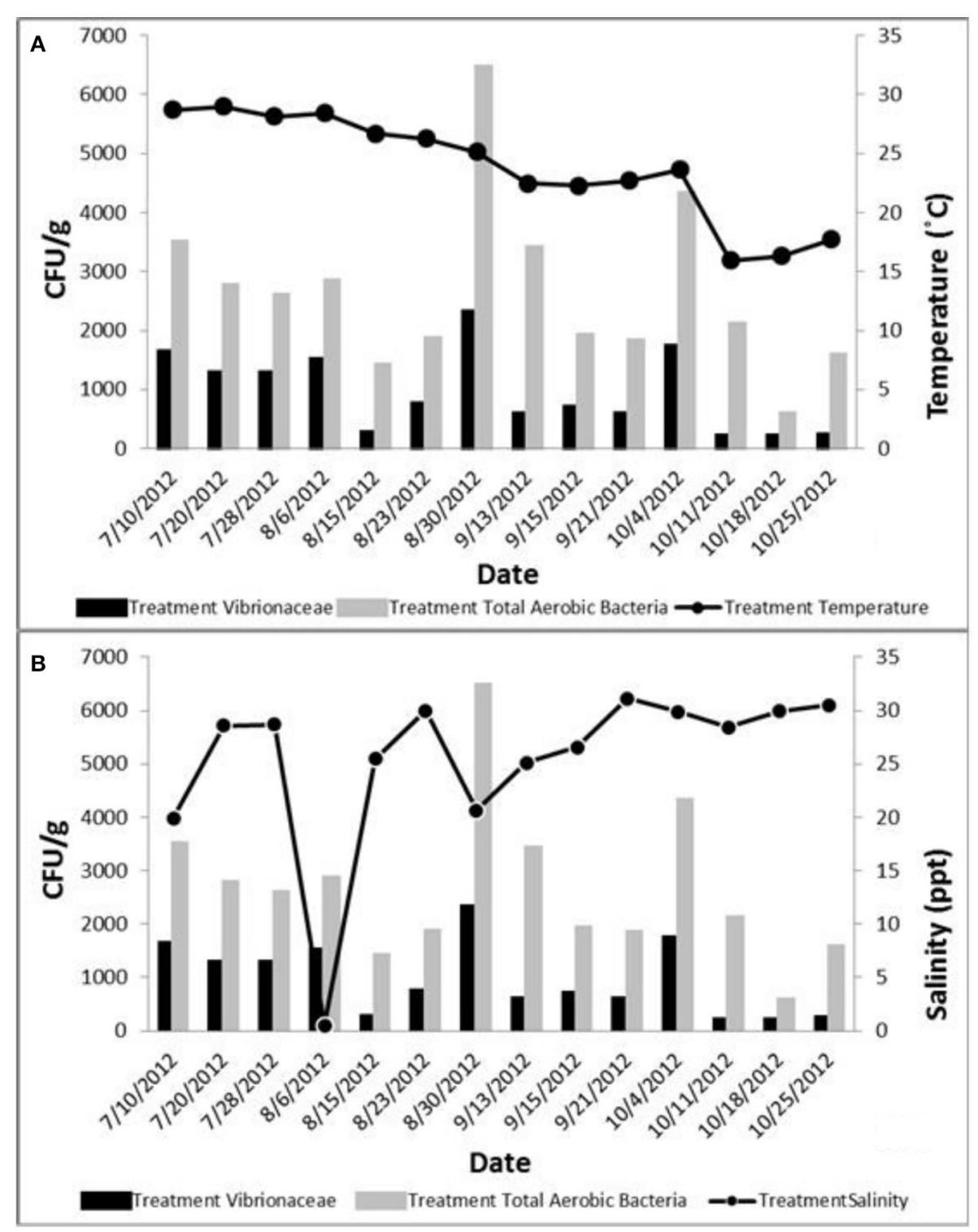

FIGURE 6 | (A) Total aerobic bacteria and Vibrionaceae levels in relation to the temperature (Hannum, 2007). (B). Total aerobic bacteria and Vibrionaceae levels in relation to water salinity (Hannum, 2007).

and at the bay site in August $\left(1.9 \times 10^{5} / \mathrm{g}\right)$. Vibrionaceae levels were significantly greater during their study timeline at the canal site $(P=0.01)$. This was the first study that monitored total aerobic bacteria and Vibrionaceae levels (2007-2008) and indeed provided the first baseline levels for total Vibrionaceae in the Delaware Inland Bays. Authors also recorded high phosphates, nitrogen, total suspended solids and low DO, which resulted in significant water quality changes that may challenge the aquatic organisms to sustain their populations.

The laboratory study focused on the colonization of naturally occurring Vibrionaceae in oysters under various water quality conditions (salinity, total suspended solids, and nitrate concentrations) in a controlled laboratory setting by Fay (2009). Of the five trials, $\sim 300$ oysters ( 60 oysters for each trial) from the Broadkill River in Lewes, Delaware were used. The rest of the oysters were randomly placed into $16-2 \mathrm{~L}$ sterile containers filled with $1.5 \mathrm{~L}$ of $1 \mu \mathrm{m}$ filtered seawater, each housing three to four oysters. Of the total 16 containers (Figure 7); three containers included a low salinity treatment of $10-15$ ppt seawater, three containers included a salinity of 20-25 ppt seawater and referred as a control, three containers had a high nitrate concentration via addition of potassium nitrate $\left(\mathrm{KNO}_{3}\right)$, and the last six containers included a high suspended solid treatment of $1,000 \mathrm{mg} / \mathrm{L}$ and a low suspended solid treatment of $100 \mathrm{mg} / \mathrm{L}$ prepared by using the settled silt particles and organic material from the Broadkill River.

The experimental units were placed in two rows in a ventilated hood. These units and oysters in them were randomly arranged 


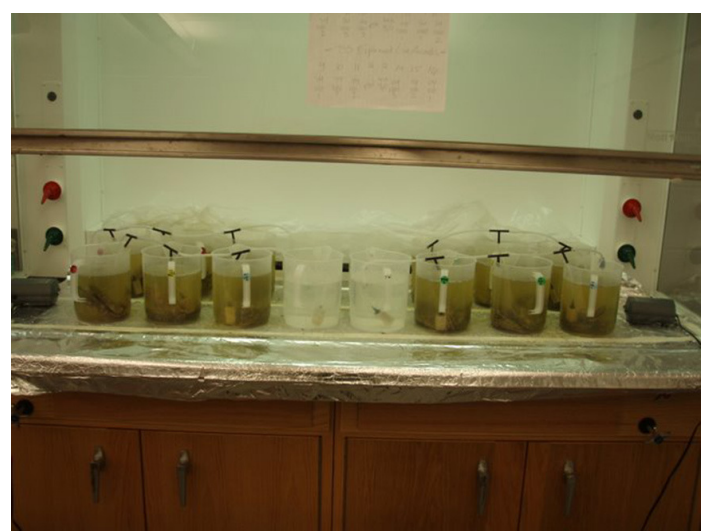

FIGURE 7 | Laboratory experiment for nitrate, salinity, and total suspended solids treatment on oyster quality (Fay, 2009).

and aerated to keep the dissolved oxygen levels above $5 \mathrm{mg} / \mathrm{L}$. Oysters were fed about $1.0 \times 10^{9}$ cells of shellfish diet 1800 (Reed Mariculture, Campbell, California) daily. Physical water quality parameters including temperature, $\mathrm{pH}$, dissolved oxygen, and salinity were monitored daily using an YSI-556 Multiprobe Unit (Yellow Springs, Ohio). After 7 days, the oysters in each container were sacrificed and COPP assay was carried out, using methodology described by Fay (2009). Broadkill River was dried and used for the total suspended solids treatment. Chemical water quality parameters from each container were tested and recorded for nitrate, nitrite, total nitrogen, total phosphorus, and total reactive phosphorus using a HACH Spectrophotometer DR2500 (Loveland, Colorado). The amount of total suspended solids in the water samples were also tested according to the standard method (Clesceri et al., 1998). In addition, the amounts of total settleble solids in each container were also determined at the end of both trials by using Imhoff cones.

During the laboratory trials, initially the total aerobic bacteria $\left(5.43 \times 10^{5}\right.$ colonies/g of oyster tissue $)$ and Vibrionaceae levels $\left(2.01 \times 10^{4}\right.$ colonies/g of oyster tissue $)$ were low in oysters but they increased in July and August with the total aerobic bacteria $\left(5.8 \times 10^{4}\right.$ colonies/g of oyster tissue $)$ and Vibrionaceae $\left(9.73 \times 10^{3}\right.$ colonies/g of oyster tissue $)$. Baseline levels of total aerobic bacteria and Vibrionaceae in the filtered seawater were $4.76 \times 10^{4}$ colonies $/ \mathrm{ml}$ of seawater and $1.4 \times 10^{4}$ colonies $/ \mathrm{ml}$ of seawater, respectively. Low salinity treated oysters yielded the highest total aerobic bacteria $\left(3.41 \times 10^{7}\right.$ colonies/g of oyster tissue) and Vibrionaceae levels $\left(6.02 \times 10^{7}\right.$ colonies/g of oyster tissue) (Fay, 2009). The authors also monitored nitrate treated oysters, which experienced higher levels of total aerobic bacteria $\left(1.59 \times 10^{7}\right.$ colonies/g of oyster tissue). Total aerobic bacteria and Vibrionaceae levels in oysters were higher in the treatment with the $100 \mathrm{mg} / \mathrm{L}$ TSS load $\left(2.81 \times 10^{5}\right.$ colonies/g of oyster tissue and $1.04 \times 10^{5}$ colonies/g of oyster tissue, respectively) than they were in the $1,000 \mathrm{mg} / \mathrm{L}$ TSS load $\left(1.66 \times 10^{5}\right.$ colonies/g of oyster tissue and $1.9 \times 10^{4}$ colonies/g of oyster tissue, respectively). However, when testing the seawater in the containers, total aerobic bacteria and Vibrionaceae levels were higher in the 1,000 $\mathrm{mg} / \mathrm{L}$ (Figure 8).

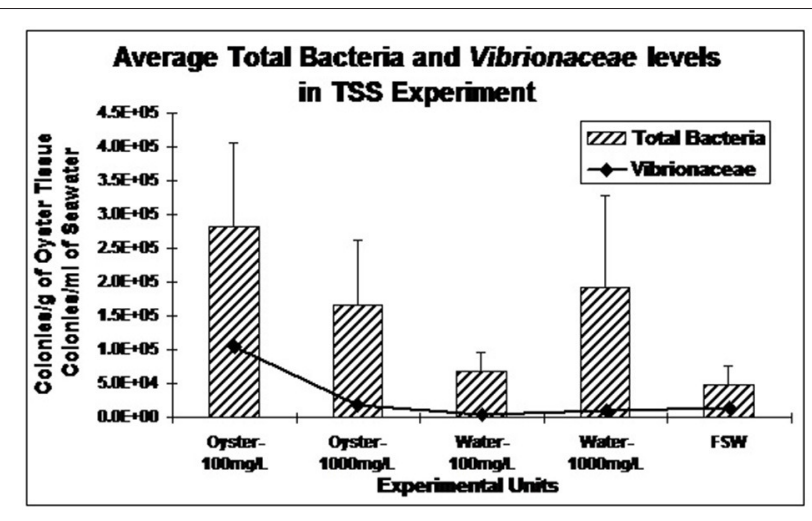

FIGURE 8 | Average total bacteria and Vibrionaceae levels ( \pm standard error) in oysters from laboratory total suspended solids experiment (Fay, 2009).

Correlations between water quality, total aerobic bacteria, and Vibrionaceae were examined. Within the control treatments, nitrite, and total suspended solids were strongly related to total aerobic bacteria ( $R^{2}=99.9$ and $92.9 \%$, respectively), while total nitrogen and total reactive phosphorus were strongly related to Vibrionaceae $\left(R^{2}=93.1\right.$ and $92.8 \%$, respectively). The increased nitrate treatments showed strong relationships between total aerobic bacteria and nitrate and nitrite $\left(R^{2}=99.4\right.$ and $99.9 \%$, respectively), whereas Vibrionaceae were strongly related to total nitrogen and total reactive phosphorus $\left(R^{2}=94.6\right.$ and $79.3 \%$, respectively). Strong relationships were observed between total aerobic bacteria and nitrate and total suspended solids $\left(R^{2}=\right.$ 90.5 and $92.5 \%$, respectively) and between Vibrionaceae and total suspended solids $\left(R^{2}=89.0 \%\right)$ in the low salinity treatments. The percent ratio of Vibrionaceae to total aerobic bacteria ranged from 14 to $94 \%$ for the control oysters, and 5 to $100 \%$ for the low salinity treated oysters, while 16 to $100 \%$ for the high nitrate treated oysters, and from 14 to $100 \%$ for the high total suspended solids treated oysters (Table 1). In three of the five trials, the low salinity treatment oysters showed that $100 \%$ of the total aerobic bacteria were Vibrionaceae; however, $100 \%$ of the total aerobic bacteria were Vibrionaceae for the high nitrate and high total suspended solids treatments in only one trial.

As Fay (2009) stated, the laboratory experiments simulated extreme conditions and created a very stressful environment for the oysters. According to Shumway (1996) and Quast et al. (1988) a salinity range of $14-28 \mathrm{ppt}$ is the optimum range for healthy oyster growth. The salinity of Broadkill River where the oysters were obtained was about 27 ppt. Without reclaiming oysters prior to experimental conditions, experimental salinity range of 15-20 ppt was applied to simulate a large freshwater input such as that from a large precipitation event causing stress to the animals. Shumway (1996) also stated silt and suspended particles reduce the pumping rate of oysters but oysters are still able to ingest the small particles. This was confirmed in our study where silt concentrations of $100 \mathrm{mg} / \mathrm{L}$ have been noted to reduce the pumping rate of adult oysters while still allowing oysters to ingest the algae and bacteria. High TSS treatment was uncharacteristically high for natural estuarine conditions 
TABLE 1 | Percent ratio of Vibrionaceae to total aerobic bacteria in oysters subjected to laboratory experiments throughout the months of July through October.

\begin{tabular}{|c|c|c|c|c|}
\hline \multirow[b]{2}{*}{ Trial } & \multicolumn{4}{|c|}{ Treatment } \\
\hline & $\begin{array}{l}\text { Control (20-25 ppt } \\
\text { salinity) (\%) }\end{array}$ & $\begin{array}{c}\text { Low salinity (10-15 ppt } \\
\text { salinity) (\%) }\end{array}$ & $\begin{array}{l}\text { High Nitrate (adding } \\
\left.\mathrm{KNO}_{3}\right)(\%)\end{array}$ & $\begin{array}{l}\text { High total suspended } \\
\text { solids (1,000 } \mathrm{mg} / \mathrm{L})(\%)\end{array}$ \\
\hline 1-July & 44 & 67 & 51 & 32 \\
\hline 2-August & 94 & 100 & 100 & 100 \\
\hline 3-August & 47 & 100 & 69 & 77 \\
\hline 4-September & 14 & 100 & 52 & 38 \\
\hline 5-October & 33 & 5 & 16 & 14 \\
\hline
\end{tabular}

and was expected to reduce oysters pumping and filtration rates. Although bacteria have been commonly associated with turbidity and suspended sediments (Cressman et al., 2003), this uncharacteristically high turbidity might have prevented oysters in the experimental units to minimize pumping and filtering that resulted low total aerobic bacteria and Vibrionaceae levels in oysters while maintaining the bacteria in the water column.

During the field trials, relationships between total bacteria and Vibrionaceae levels with total nitrogen, total phosphorus and total suspended solids from the bay and canal study sites are shown in Figure 5 through Figure 9B. Fay et al. (2011) analyzed relationship between the total nitrogen and bacteria and Vibrionaceae levels. She did not observe the relationships between those parameters however, total nitrogen levels were much lower than the maximum recommended levels and no clear trends or effects of nitrogen on the bacterial levels were recorded for both bay and canal study sites (Figure 9A). Data analysis revealed higher phosphorus levels in the canal site than the bay site and relationship is stronger between total bacteria and Vibrionaceae levels and the phosphorus levels. Higher the total phosphorus, the higher the total bacteria and Vibrionaceae levels (Figure 9B).

Although added total suspended solids (silt and clay) posed some stresses on the oysters, almost all oysters survived and it did not stop oysters' pumping during the 7-day experimental period. In order to ensure live oysters were pumping and filtering water, additional experimental units were added that contained only oyster shells without live oysters. Daily observation allowed the researcher to confirm live oysters were filtering the water and picking up algal feed while the units with only oyster shells experiment retained the fed algae in the water column. Although the salinity treatments had the highest total aerobic bacteria and Vibrionaceae levels, the data was weakly related to the nutrients as this was confirmed during the field trials. Therefore, this study confirms that aerobic bacteria and Vibrionaceae levels are salinity dependent. No clear trends were observed with regards to seasonality and timeliness of the trials in relation to total aerobic bacteria and/or Vibrionaceae levels. Perhaps mimicking natural conditions using natural aggregates and plant materials and other organic particles in the water during the laboratory experiments will provide more accurate and reliable relationships between the environmental parameters and total aerobic bacteria and Vibrionaceae levels in oysters. This will be of tremendous help to the commercial shellfish aquaculture farms to predict poor conditions to prevent oyster consumption when bacterial levels are high in water.

\section{Case Studies-Oyster Revitalization Oyster Revitalization in Delaware Inland Bays Summary}

Commercial aquaculture has the potential to dramatically increase the abundance of shellfish. Cultured oysters may also serve as brood stock, contributing to enhance and promote naturally occurring populations in the bays. Oyster gardening provides a unique opportunity to observe many of the important ecological services provided by oysters. The oyster gardeners had about 200 oysters at their docks and a total of about 40,000 oysters were used during the oyster gardening program over 12 years in Delaware Inland Bays. Delaware Inland Bays has a surface area of $83 \mathrm{~km}^{2}$, with an average depth of $1.23 \mathrm{~m}$. This makes for a total volume of 105 billion liters. In order to filter the volume of water in the Inland Bays once daily, would take at least 534 million more oysters. Considering this number, and the fact that each oyster filters $\sim 189$ $L$ of water per day, the oysters involved in the program filtered about 7.6 million liters of water per day in the Inland Bays.

Delaware's Inland Bays are very shallow and poorly flushed by tidal movement; they are especially sensitive to environmental changes. In response to the detrimental decline of oysters, conservation organizations developed community involvement programs commonly referred to as "oyster gardening" to help restore the oyster population. The use of community volunteers to help rear oysters for restoration has become a common practice throughout the Mid-Atlantic region. Oyster gardening encompasses the progression of oysters' life from spat in the remote set tank, to juvenile oysters in floating aquaculture gear, to adult oysters planted throughout the bays using various aquaculture techniques.

The Delaware Oyster Gardening Program was initiated during the summer of 2003, and was a cooperative effort among the Delaware Center for the Inland Bays (CIB), the Delaware Sea Grant Marine Advisory Program, Delaware State University and citizen volunteers living along the waterfront on one of Delaware's three coastal or "Inland" Bays: Rehoboth, Indian River, and the Little Assawoman (Marenghi et al., 2010). Oyster gardening is the nursery culture of small, hatchery-produced oysters, called "seed" or "spat" to a larger "juvenile" size, which is then for stocking artificial oyster reefs and for other 


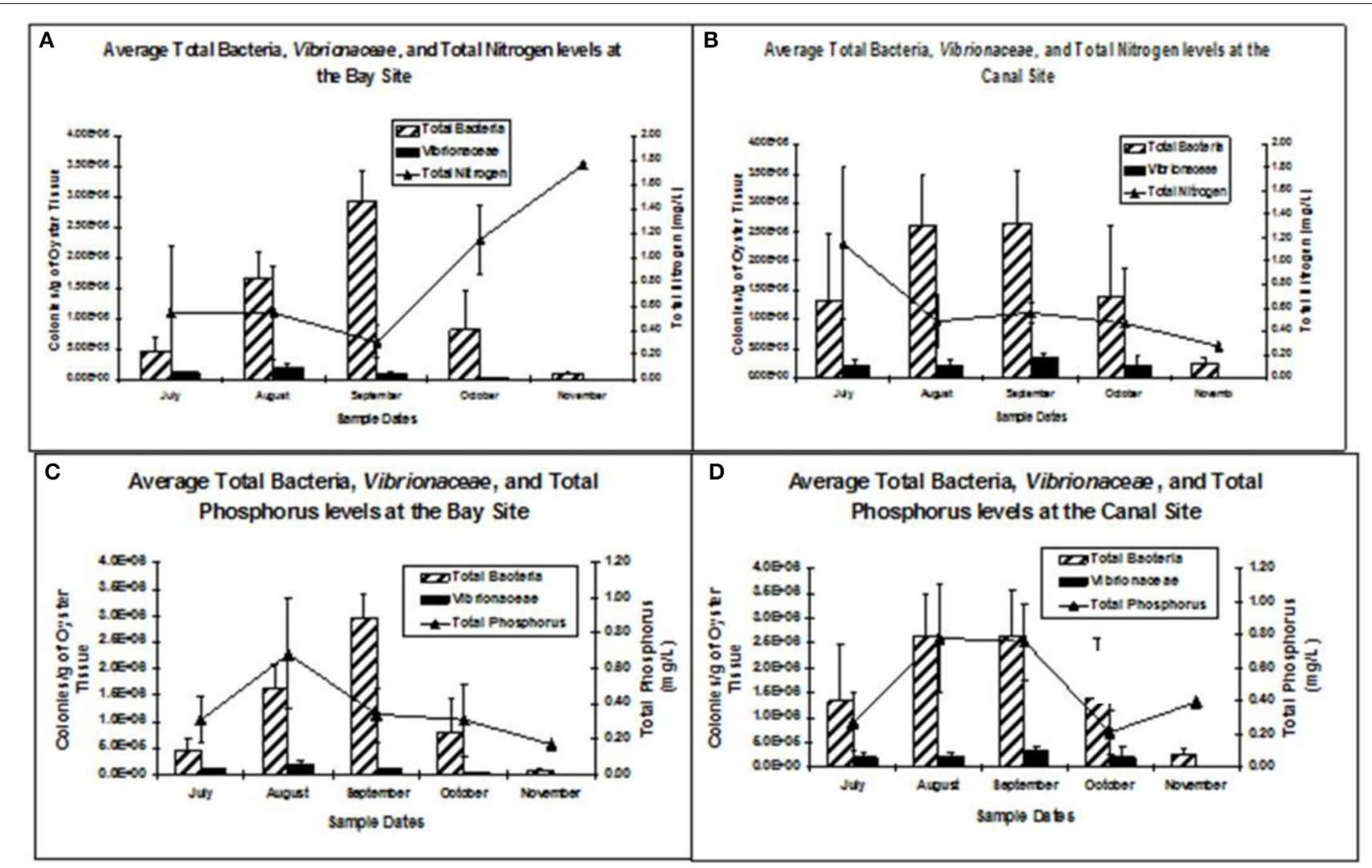

FIGURE 9 | (A) Average total aerobic bacteria and Vibrionaceae levels ( \pm standard error) in oysters in relation to total nitrogen levels in the bay and canal study sites (Fay, 2009). (B). Average total aerobic bacteria and Vibrionaceae levels ( \pm standard error) in oysters in relation to total nitrate levels in the bay and canal study sites (Fay, 2009).

shellfish restoration projects. 200 volunteers living in the local communities surrounding the $83 \mathrm{~km}^{2}$ of surface area of the Inland Bays participated in the oyster gardening program. They placed floating baskets of oysters at the ends of their docks to allow the filter-feeders a safe haven to grow from small, young spat into thriving adult oysters (CIB, 2014; Marenghi and Ozbay, 2010).

In order to supply gardeners with the new-year class, diseaseresistant oyster larvae were obtained from Rutgers University's Haskin Shellfish Laboratory. A remote setting process was then used to allow the larvae to settle on cultch bags, hanging baskets or trays. Volunteer gardeners supported the program by caring for small 6-7 $\mathrm{mm}$ spat attached to old oyster shell by holding them in baskets placed in Taylor floats tied to their docks, and participated in small-scale aquaculture providing ecosystem function (Figure 10). Oysters held off the bottom have better conditions for growth-increased water flow and greater access to particulate food-so they reach a planting size of $25-50 \mathrm{~mm}$ $(\sim 2$ years of age) much more rapidly than oysters on the bottom (Ewart et al., 2008).

During the last few decades, the ecological effects of oysters (C. virginica) raised with commercial aquaculture gear have been researched with a focus to move the oyster aquaculture forward and allow industry to move away from a wild fishery harvest in order to meet consumer demands. Years of research efforts to measure biodiversity in and around the oyster gear is one of the significant ways to evaluate the full impact of these culture operations on the ecosystem fully. Years of research efforts suggest culturing shellfish in high densities in shallow water can have positive effects on the environment and promote biodiversity and enhance habitat quality. Figure 11 below shows the increased abundance of species with presence of live oysters and oyster shells in the habitat. Similar to other shellfish culturing efforts, aquaculture equipment used by the volunteer oyster gardeners in Delaware Inland Bays has provided a venue to educate the public and increase public awareness for water quality and estuarine health.

\section{CONCLUSION}

The threat of heavy metals, excess nutrients, and bacterial contamination to human and aquatic health in coastal Delaware has become a public concern as human population increase and land development continues. Delaware's coastal lagoons have been subjected to problems commonly shared by the coastal MidAtlantic States. Delaware inland waters have been exposed to various anthropogenic pressures due to various land use activities and agriculture is the primary contributor of nutrients to this 


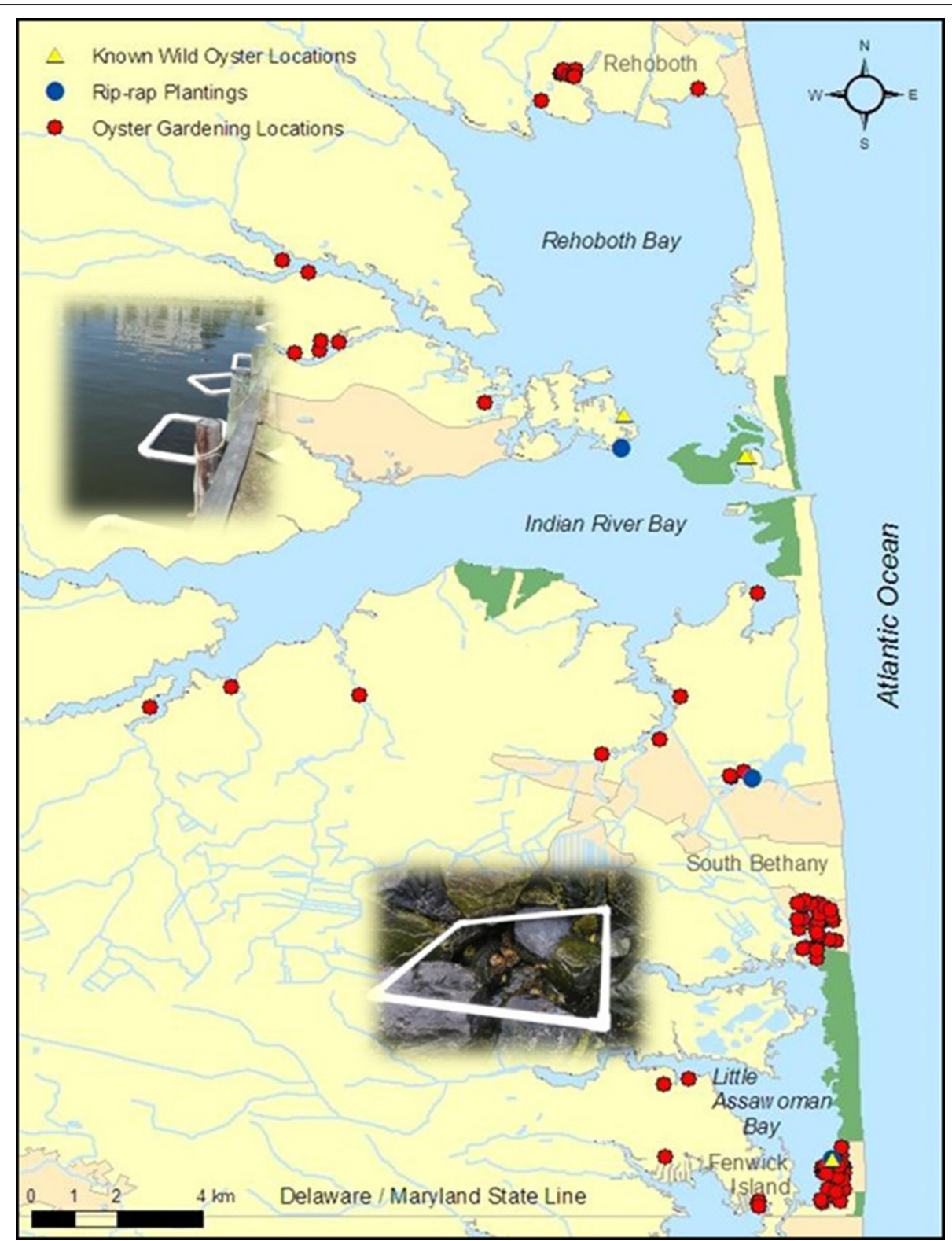

FIGURE 10 | Map includes Delaware's Inland Bays oyster gardening locations, rip-rap planting locations, and known wild oyster locations (Marenghi, 2009; Reckenbeil, 2013).

bay. Although excess nutrient issues have been managed much better in some parts of the bays by minimizing point discharge pollution, reports still indicate increased nutrient levels. Also, Delaware has regionally medium levels of cadmium and high levels of lead. The cumulative impact of pollutants from runoff and point sources has degraded water quality and reduced the diversity and abundance of various fish species, invertebrates, and submerged aquatic vegetation. These effects are especially pronounced within the manmade dead end canal systems. Over $600 \mathrm{~km}$ of Delaware's shoreline includes barrier beaches, inland bays, small islands, and highly productive estuaries that are home to a variety of plants, animals, insects, migratory birds, and other terrestrial and aquatic wildlife. Our studies were initiated to monitor the levels of heavy metals, nutrients, and microbial loads in the waters and oysters present in the waters of Delaware Inland Bays.

Oysters are other key ecosystem components that help in the uptake and recycling of nutrients. Shellfish are successfully used as indicators to monitor water quality due to the bioaccumulation of microorganisms and other pollutants from its surrounding environment. Vibrionaceae is one of the foremost occurring bacterial groups in estuarine and coastal environments worldwide. Data analysis revealed higher phosphorus levels in the canal site than the bay site and relationship is 


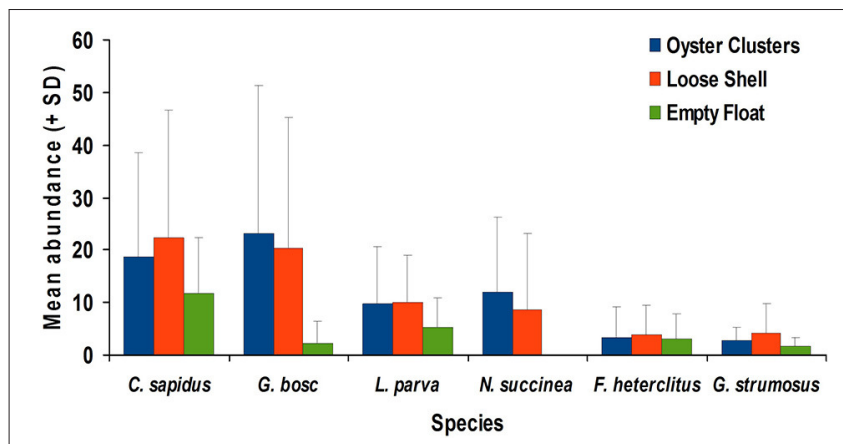

FIGURE 11 | Average abundance (+std) for six species collected from Little Assawoman Bay in comparative study using live oyster clusters, loose shells, and empty floats. Data were pooled across months (Marenghi, 2009).

stronger between total bacteria and Vibrionaceae levels and the phosphorus levels. The higher the levels of total phosphorus in the waters, the greater are the levels of total bacteria and Vibrionaceae in the oysters. The relationships between eastern oysters (C. virginica) and their surrounding environmental parameters, microbial loads and nutrient levels in the waters of Delaware Inland Bays were investigated as an indicator of the aquatic health. Oysters at comparatively low saline treatments had the highest total bacteria and Vibrionaceae levels, followed by increase in total bacteria in oysters treated with high nitrate and total suspended solids. Data collected over the last 10 years may be used to build a predictive index of conditions that are favorable for the proliferation of human and fish pathogenic bacteria. Such data can further benefit the aquaculture and human health industries to avoid vibrio outbreaks, heavy metal contamination, and potential pathogenic threats. The results from this study provide information about shellfish restoration and seafood protection in Delaware Inland Bays. This information will be

\section{REFERENCES}

Akpor, O. B., and Muchie, M. (2010). Remediation of heavy metals in drinking water and wastewater treatment systems: processes and applications. Int. J. Phys. Sci. 5, 1807-1817. Available online at: http://www.academicjournals.org/ journal/IJPS/article-full-text-pdf/00E529A31916

Brumbaugh, R. D., Sorabell, L. A., Garcia, C. O., Goldsborough, W. J., and Wesson, J. A. (2000). Making a case for community-based oyster restoration: an example from Hampton Roads, Virginia, U.S.A. J. Shellfish Res. 19, 467-472.

Cannon, A., Chintapenta, L. K., and Ozbay, G. (in press). Monitoring heavy metals near wastewater facility in Delaware Inland Bays tidal canal. J. Water Resour. Prot.

CDC (2013). Increase in Vibrio parahaemolyticus Illnesses Associated with Consumption of Shellfish from Several Atlantic Coast Harvest Areas, United States, 2013. Centers for Disease Control and Prevention. Available online at: https://www.cdc.gov/vibrio/investigations/vibriop-09-13/index.html

Chaillou, J. C., DeMoss, T. E., Eskin, R., Kutz, F. W., Magnien, R., Mangiaracina, L., et al. (1996). Ecological Condition of the Delaware and Maryland Coastal Bays: Assessment of the Ecological Condition of the Delaware and Maryland Coastal Bays U.S. Environmental Protection Agency 20460 EPA/620/R-96/004, 118. Available online at: https://archive.epa.gov/emap/archive-emap/web/html/cb_ exsumm.html (Washington, DC) shared with the resource managers, public, and the state agencies that have common interests in these geographical locations.

\section{AUTHOR CONTRIBUTIONS}

GO as the program director, lead all the projects conducted in the article, and formulated the topic and idea, collected information, initiated, and supervised the research, wrote and compiled article. LC assisted GO with every aspects of this review article from planning, dissemination, and execution. AC conducted one of the case studies included in this article and assisted GO with dissemination of information on that section. $\mathrm{KH}$ conducted another case study included in this article and provided information and data for the article.

\section{FUNDING}

NSF-EPSCoR Program Award\# EPS-1301765, USDA EvansAllen Grant Award\# DELXDSUGO2015, USDA-NIFA CBG Grant Award\# 2010-38821-21454, NSF SMILE Program Award $\# 0928404$.

\section{ACKNOWLEDGMENTS}

Authors would like to thank the following individuals for their assistance with the research, article preparation, and reviews: Laurieann Phalen, Eunice Handy, Talaysha Lingham, and Katherine Ommanney. We would like to thank Dr. Venu Kalavacharla for his support for the project and undergraduate students involved in the projects. The research discussed in this article are funded by various funding agencies (NSF-EPSCOR, USDA-NIFA Capacity Building Grant Programs, USDA EvansAllen Grant, Delaware Water Resources Center, and NSF SMILE Program) with NSF EPSCOR being the primary funding sources for the most of the projects in this article.

CIB (2014). About the Bays: Issues Affecting the Bays Center for the Inland Bays. Available online at: http://www.inlandbays.org/about-the-bays.

Clesceri, L. S., Greenburg, A. E., and Eaton, A. D. (1998). Standards Methods for the Examination of Water and Wastewater 20th Edn. American Public Health Association. Available online at: https://www.mwa.co.th/download/file_ upload/SMWW_1000-3000.pdf

Cressman, K. A., Posey, M. H., Mallin, M. A., Leonard, L. A., and Alphin, T. D. (2003). Effects of oyster reefs on water quality in a tidal creek estuary. J. Shellfish Res. 22, 753-762.

Cruz-Romero, M., Kerry, J. P., and Kelly, A. L. (2008). Changes in the microbiological and physicochemical quality of high-pressure-treated oysters (Crassostrea gigas) during chilled storage. Food Control 19, 1139-1147. doi: 10.1016/j.foodcont.2007.12.004

Delaware Inland Bays Estuary Report (1993). Delaware Inland Bays Estuary: Technical Appendix 4.6-3.

Delaware Sea Grant (2016). Seafood Health Facts: Making Smart Choices Balancing the Benefits and Risks of Seafood Consumption. Resources for Healthcare Providers and Consumers. Delaware Sea Grant, National Oceanic and Atmospheric Association; U.S. Department of Commerce and the National Integrated Food Safety Initiative; National Institute of Food and Agriculture; U.S. Department of Agriculture. Available online at: http://www. seafoodhealthfacts.org/ 
DePaola, A. (2013). "Vibrio species. Vibrio vulnificus," in Bad Bug Book, Handbook of Foodborne Pathogenic Microorganisms and Natural Toxin, ed K. A. Lampel (Washington, DC: U.S. Food and Drug Administration), 292.

DePaola, A., Hopkins, L. H., Peeler, J. T., Wentz, B., and McPherson, R. M. (1990). Incidence of Vibrio parahaemolyticus in U.S. coastal waters and oysters. Appl. Environ. Microbiol. 56, 2299-2302.

DePaola, A., Nordstrom, J. L., Bowers, J. C., Wells, J. G., and Cook, D. W. (2003). Seasonal abundance of total and pathogenic Vibrio parahaemolyticus, in Alabama oysters. Appl. Environ. Microbiol. 69, 1521-1526. doi: 10.1128/AEM.69.3.1521-1526.2003

DNREC (2005). Delaware Bay and Estuary Assessment Report, Whole Basin, 1-71. Doc. No. 40-01-01/05/02/01. Available online at: http://www.dnrec.delaware. gov/WholeBasin/Documents/DelawareBayAssessmentPages.pdf

EPA (1985). Ambient Water Criteria for Lead - 1984 United States Environmental Protection Agency USEPA Report 440/5-84-027. Washington, DC.

EPA (2001). Update of Ambient Water Quality Criteria for Cadmium United States Environmental Protection Agency USEPA Report 822-R-01-001. Washington, DC.

EPA (2011). USEPA Regional Screening Level (RSL) Summary Table United States Environmental Protection Agency. Washington, DC.

Ewart, J. W., Chalabala, E. J., Marenghi, F., and Gibson, A. (2008). "A communitybased oyster restoration strategy for Delaware's Coastal (Inland) Bays," in 11th International Conference on Shellfish Restoration (ICSR). (Charleston, SC).

Fay, J. P. (2009). An Investigation of the Relationship between Water Quality, Total Bacteria, and Vibrionaceae Concentrations in Eastern Oysters (Crassostrea virginica) in Delaware. Delaware State University, (Dover, DE), 138.

Fay, J., Richards, G. P., and Ozbay, G. (2011). Water quality parameters and total aerobic bacterial and Vibirionaceae loads in eastern oysters (Crassostrea virginica) from oyster gardening sites. Arch. Environ. Contam. Toxicol. 64, 628-637. doi: 10.1007/s00244-011-9736-1

FDA (2015). Vibrio vulnificus Bad Bug Book: Foodborne Pathogenic Microorganisms and Natural Toxins Handbook. U.S. Food and Drug Administration. Available online at: http://www.fda.gov/Food/FoodborneIllnessContaminants/ CausesOflllnessBadBugBook/ucm070473.html

FDA (2016). Vibrio vulnificus Health Education Kit Fact Sheet: Raw Oysters Contaminated with Vibrio vulnificus Can Cause Illness and Death. U.S. Food and Drug Administration. Available online at: http://www.fda.gov/Food/ ResourcesForYou/HealthEducators/ucm/085365.htm (Accessed February 25, 2016).

Froelich, B. A., Williams, T. C., Noble, R. T., and Oliver, J. D. (2012). Apparent loss of Vibrio vulnificus from North Carolina oysters coincides with a drought-induced increase in salinity. Appl Environ. Microbiol. 78, 3885-3889. doi: 10.1128/AEM.07855-11

Garbarino, J. R., Hayes, H. C., Roth, D. A., Antweiler, R. C., Brinton, T. I., and Taylor, H. E. (1995). Contaminants in the Mississippi River. U.S. Geological Survey Circular 1133. Reston, VA.

Globetti, M. (2015). DNREC Moves City of Rehoboth Beach Wastewater Disposal Financing Forward and Agrees to New Discharge Removal Deadline Delaware. Department of Environmental Resources and Environmental Control. Available online at: http://www.dnrec.delaware.gov/News/Pages/DNRECmoves-City-of-Rehoboth-Beach-wastewater-disposal-financing-forwardand-agrees-to-a-new-discharge-removal-deadline.aspx (45)2 (Accessed November28, 2016).

Hannum, K. (2007). Investigating the Relationship between Environmental Quality and Total Bacteria and Vibrionaceae Densities in Eastern Oysters, Crassotrea virginica, in the Lewes-Rehoboth Canal, Delaware. Graduate Thesis, Master of Sciences in Natural Resources, Natural Resources Program, Department of Agriculture and Natural Resources, Delaware State University, Dover, DE

Hoi, L., Larsen, J. L., Dalsgaard, I., and Dalsgaard, A. (1998). Occurrence of Vibrio vulnificus biotypes in Daniah marine environments. Appl. Environ. Microbiol. $64,7-13$

Iwamoto, M., Ayers, T., Mahon, B. E., and Swerdlo, D. L. (2010). Epidemiology of seafood-associated infections in the United States. Clin. Microbiol. Rev. 23, 399-411. doi: 10.1128/cmr.00059-09

Johnson, C. N., Bowers, J. C., Griffitt, K. J., Molina,V., Clostio, R. W., Pei, S., et al. (2012). Ecology of Vibrio parahaemolyticus and Vibrio vulnificus in the coastal and estuarine waters of Louisiana, Maryland, Mississippi, and Washington (United States). Appl. Environ. Microbiol. 78, 7249-7257. doi: 10.1128/AEM.01296-12

Kaspari, C. W., and Tamplin, M. L. (1993). Effects of temperature and salinity on the survival of Vibrio vulnificus in seawater and shellfish. Appl. Environ. Microbiol. 59, 2425-2429.

Kelly, M. T. (1982). Effects of temperature and salinity on Vibrio (Beneckea) vulnificus occurrences in the Gulf coast environment Appl. Environ. Microbiol. $44,820-824$.

Kimbrough, K. L., Johnson, W. E., Lauenstein, G. G., Christensen, J. D., and Apeti, D. A. (2008). An Assessment of Two Decades of Contaminant Monitoring in the Nation's Coastal Zone. Sliver Spring MD: NOAA Technical Memorandum NOSNCCOS74, 105

Klontz, K. C., and Rippey, S. R. (1991). "Epidemiology of the molluscan-borne illnesses," in Molluscan Shellfish Depuration, eds W. S. Otwell, G. E. Roderick, and R. E. Martin (Boca Raton, FL: CRC Press), 47-58.

Lyons, M. M., Lau, Y., Cardin, W. E., Ward, J. E., Roberts, S. B., Smolowitz, R., et al. (2007). Characteristics of marine aggregates in shallowwater ecosystems: implications for disease ecology. Ecohealth 4, 406-420. doi: 10.1007/s10393-007-0134-0

MacKenzie, J., Martin, J. H., Pintea, L., Boonmee, B., Gedamu, N., and Thomas, T. C. (2016). Delaware Inland Bays Watershed Nutrient Management Project. University of Delaware Spatial Analysis Lab. Available online at: http://www. udel.edu/FREC/spatlab/spot/ (Accessed February 12, 2016).

Marenghi, F. P. (2009). Floating oyster (Crassostrea virginica) aquaculture as Habitat for Fishes and Macroinvertebrates in Delaware's Inland Bays. Delaware State University (Dover, DE), 203.

Marenghi, F. P., and Ozbay, G. (2010). Floating Oyster, Crassostrea virginica Gmelin 1791, Aquaculture as habitat for fishes and macroinvertebrates in Delaware Inland Bays: the comparative value of oyster clusters and loose shell. J. Shellfish Res. 29, 889-904. doi: 10.2983/035. 029.0422

Marenghi, F. P., Ozbay, G., Erbland, P., and Rossi-Snook, K. (2010). A comparison of the habitat value of sub-tidal and floating oyster (Crassostrea virginica) aquaculture gear with a created reef in Delaware's Inland Bays, USA. Aquacult. Int. 18, 69-81. doi: 10.1007/s10499-0099273-3

Motes, M. L., DePaola, A., Cook, D. W., Veazey, J. E., Hunsucker, J. C., Garthright, W. E., et al. (1998). Influence of water temperature and salinity on Vibrio vulnificus in northern Gulf and Atlantic coast oysters. Appl. Environ. Microbiol. 64, 459-1465.

NOAA (2004). Population Trends along the Coastal United States 1980-2008. Coastal Trends Report Series. Available online at: http://oceanservice.noaa.gov/ programs $/ \mathrm{mb} / \mathrm{pdfs} /$ coastal_pop_trends_complete.pdf

NOAA NMFS (2007). Status Review of the Eastern Oyster (Crassostrea viriginica). Report to the National Marine Fisheries Service; Northeast Regional Office, NOAA Fisheries Eastern Oyster Biological Review Team; NOAA Technical Memorandum NMFS-F/SPO-88.

NOAA NMFS (2012). Fisheries of the United States- Current Fisheries Statistics No. 2012. U.S. Department of Commerce; National Oceanic and Atmospheric Administration, and National Marine Fisheries Service. Available online at: https://www.st.nmfs.noaa.gov/Assets/commercial/fus/fus12/FUS2012.pdf.

O'neill, K. R., Jones, S. H., and Grimes, D. J. (1992). Seasonal incidence of Vibrio vulnificus in the Great Bay estuary of New Hampshire and Maine. Appl. Environ. Microbiol. 58, 3257-3262.

Oregon Health Authority (2016). Joint OHA, ODA, DEQ, ODFW Statement on PSU Oyster Study. Oregon Health Authority. Available online at: http://www. oregon.gov/oha/news/Pages/Joint\%20OHA,\%20ODA,\%20DEQ,\%20ODFW \%20statement\%20on\%20PSU\%20oyster\%20study.aspx

Pérez-Mateos, M., López-Caballero, M. E., and Montero, P. (2002). Effect of high pressure and 4-hexylresorcinol on enzymatic activity and darkening in oysters. J. Food Sci. 67, 2107-2112. doi: 10.1111/j.1365-2621.2002. tb09509.x

Pfeffer, C. S., Hite, M. F., and Oliver, J. D. (2003). Ecology of Vibrio vulnificus in estuarine waters of Eastern North Carolina Appl. Environ. Microbiol. 69, 3526-3531. doi: 10.1128/AEM.69.6.3526-3531.2003

Quast, W. D., Johns, M. A., Pitts, D. E. Jr.,, Matlock, G. C., and Clark, J.E. (1988). Fishery Management Plan Series Number 1: Texas Oyster Fishery Management Plan Texas Parks and Wildlife Department, Coastal Fisheries, 178. Austin, TX. 
Randa, M. A., Polz, M. F., and Lim, E. (2004). Effects of temperature and salinity on Vibrio vulnificus population dynamics as assessed by quantitative PCR. Appl. Environ. Microbiol. 70, 5469-5476. doi: 10.1128/AEM.70.9.5469-54 76.2004

Reckenbeil, B. A. (2013). Assessment of Oyster Restoration along Human Altered Shorelines in the Delaware Inland Bays: An Examination of Rip-Rap Stocked with the Eastern Oyster (Crassostrea virginica). Delaware State University Natural Resources Program, 174.

Richards, P. G., Watson, M. A., and Parveen, S. (2005). Development of a simple and rapid fluorogenic procedure for identification of Vibrionaceae family members. Appl. Environ. Microbiol. 71, 3524-3527. doi: 10.1128/AEM.71.7.3524-3527.2005

Shumway, S. E. (1996). "Natural environmental factors," in The Eastern Oyster: Crassostrea virginica Maryland Sea, eds. V. S. Kennedy, R. I. E. Newell, and F. Eble (Grant, MI: College Park Maryland), 467-513.

Singleton, F. L., Atwell, R. W., Jang, M. S., and Colwell, R. R. (1982). Influence of salinity and organic nutrient concentrationon survival and growth of Vibrio cholerae in aquatic microcosms. Appl. Environ. Microbiol. 43, 1080-1085.

Stenger, R. (2008). City of Rehoboth Beach Wastewater Treatment Facilities: A Historical Narrative City of Rehoboth. Available online at: https://www.cityofrehoboth.com/sites/default/files/Bob_Stenger_CityWastewater DepartmentPresentation06-16-08_1.pdf (Accessed October 18, 2016)

Taylor, J. (2013). Is It Ok to Eat Raw Shellfish: Seafood is Safe to Eat. Mariner's Menu. Available online at: http://marinersmenu.org/category/seafood-is-safe-to-eat/ (Accessed February)
Warner, E., and Oliver, J. (2008). Population structures of two genotypes of Vibrio vulnificus in oysters (Crassostrea virginica) and seawater. Appl. Environ. Microbiol. 74, 80-85. doi: 10.1128/AEM. 01434-07

Weisbecker, A. (2010). Oysters, a Simple Food with a Complicated history: Food Safety News. Available online at: http://www.foodsafetynews.com/2010/ 02/oysters-a-simple-food-with-a-complicated-history/\#.VpCMyvkrK00. (Accessed December 20, 2015)

Wright, A. C., Hill, R. T., Johnson, J. A., Roghman, M., Colwell, R. R., and Morris, J. G. (1996). Distribution of vibrio vulnificus in the Cheasapeake bay. Appl. Environ. Microbiol. 62, 717-724.

Zhen-Gang, J. (2008). Hydrodynamics and Water Quality: Modeling Rivers, Lakes, and Estuaries. New Jersey, NJ: Wiley.

Conflict of Interest Statement: The authors declare that the research was conducted in the absence of any commercial or financial relationships that could be construed as a potential conflict of interest.

Copyright (c) 2017 Ozbay, Chintapenta, Cannon and Hannum. This is an openaccess article distributed under the terms of the Creative Commons Attribution License (CC BY). The use, distribution or reproduction in other forums is permitted, provided the original author(s) or licensor are credited and that the original publication in this journal is cited, in accordance with accepted academic practice. No use, distribution or reproduction is permitted which does not comply with these terms. 